\title{
The Influence of Domestic Politics of South Korea on its Relations with North Korea and the United States
}

\author{
Miftah Farid Darussalam \\ Department of International Relations, UIN Alauddin Makassar \\ (email: darussalam.farid@gmail.com)
}

\begin{abstract}
This paper aims to conduct research on the influence of domestic South Korean politics on relations with the United States and North Korea. In this case, the theory of dominance of domestic political actors explains where the dominance of a group will have an influence on determining the foreign policy of a country. South Korea's domestic politics is dominated by two groups with different ideologies in the face of the United States and North Korea. This then resulted in different actions in the face of North Korea and the United States. The differences will be explained by assessing some of the policies applied to Kim Dae Jung's regime and Roh Moo-Hyun from a progressive group. The policy will then be compared to the policies of the regime of Lee Myung Bak from conservative groups. Differences in the group's dominant views in South Korea have led to certain strategies for each group in the face of the opposition group. The strategy is carried out to maintain the effectiveness of the policies applied according to the ideology of each group. This research used literature study as the method by taking data from journals and reports which that discuss the national politics of South Korea. The theoretical framework of V.M Hudson, which focuses on the national circumstances, and the role of domestic actors have been applied in this research.
\end{abstract}

Keywords:

South Korea; conservative; progressive; domination of domestic political actors; regime strategy

\section{Introduction}

South Korea is one of the countries which has a significant influence in affecting the condition of international politics among South Korea, North Korea and the United States. On the other hand, South Korea is one of the most loyal US allies. However, on the other hand, South Korea is bordered and conflicts with North Korea. Therefore, when the relationship between South Korea and the United States is strong, the relationship between South Korea and North Korea becomes weak. The difference of foreign policy between Kim Dae Jung, Roh Moo Hyun and Lee Myung Bak impacts the relationships between the U.S, South Korea and North Korea. The difference is representing two political groups with different ideologies in affecting South Korea foreign policy, especially in facing North Korea and the United States. One group is conservative and the group is progressive (Ho, 2012).

In Kim Dae Jung's regime, South Korea tried to make a policy by opening cooperation with North Korea. One of the policies in Kim Dae Jung's government is known as the Sunshine Policy. The Sunshine Policy was aimed at building economic cooperation with North Korea (Junior, 2015). It was also done by Roh Moo-Hyun in his government to invite North Korea to join the Six Party Talks Negotiations (Park L. , 2006). However, in Lee Myung Bak's government, the policy has contrasted from the regime before. The difference is indicated by policy that is closer to 
the United States and applied more provocative policy towards North Korea (Konishi, 2009). Both of these groups' ideological differences will influence the direction of South Korea's foreign policy. Every group will use certain strategies in competing to influence South Korea's foreign policy. Therefore, condition and domination from a group in South Korea will influence different actions in facing North Korea and the United States.

The differences in the direction of foreign policy in each South Korean government regime have an impact on the international political conditions among three countries. The differences emphasize the power of two political groups, the conservative and progressive group which have different ideologies in South Korea (Ho, 2012). These two groups have influenced South Korea's foreign policy and relationships with North Korea and the United States. For example, once South Korea tried to get closer to North Korea-this was the result of the progressive group. North Korea will react towards the US by using its hard power. In addition, the policy also had an effect nationally where the position of US troops in South Korea was increasingly criticized by the domestic community. As a result, the relations between South Korea and the US became tenuous. In contrast, when South Korea chose to improve their relations with the United States, the tension between South Korea and North Korea increased. As North Korea developed nuclear weapons, South Korea increased its military power with the help of the United States, particularly in the DMZ. Hence, this research will look at this condition closely to analyze the dynamic of South Korea's foreign policy towards the United States and North Korea in the future. In addition, it would emphasize the relations among these three countries from the perspective of South Korea.

In this article, the theory of V.M Hudson, which focuses on the influence and the domination of national actors in a foreign policy is applied. As South Korea has a government structure that fits into Hudson's chart, also the ideology of democracy which provides an opportunity for every actor to influence in the determination of a country's policy is one of the considerations in using this theory.

Hudson is explaining the dominance of domestic political actors in shaping foreign policy. Some factors that can assess the dominance of domestic political actors can be seen in the position of the actor's proximity to foreign policy making. The closer the actor's position with foreign policy, the greater the dominance and power the actor possesses in determining foreign policy. Hudson describes an illustration to explain the position of domestic political actors against foreign policy making as follows (Hudson, 2007):

\section{Figure 1. The Proximity to FPDM of Political Domestic Actor}

Executive Senate Democratic Business Public UNFCCC Department Republicans Party Media Group Society Member

Executive Government Political Active Broader Society Foreign Segment

Greater Proximity to Governmental Decision Making

Source: V.M. Hudson, Foreign Policy Analysis: Classic and Contemporary Theory, Rowman E Littlefield, Maryland, 2007

“The State Department arguably is more proximate to foreign policy decision making power than other members of the larger government, such as the Senate Republicans" (Hudson, 2007, p. 146). The illustration explains that the state executive or president has the greatest influence in determining the policy. The Senate Republican is closer than the Democratic Party and Media. Actors in the Politically Active Segment are considered closer when compared to actors which exist in Broader Society such as business groups and social communities (Hudson, 2007, p. 146). 
The next factors are to assess how cohesive and fragmented domestic political actors who are involved in foreign policy making. A regime can be classified in a fragmented condition when there is no dominant group inside the regime. However, the regime that can be classified as cohesive is a regime that has or follows a leader, is followed by several groups, and is able to share power against minority parties. The more cohesive domestic political actors, the fewer constraints faced in determining foreign policy. The more fragmented a regime, the more obstacles in determining foreign policy. It will give impact to more ambiguous behavior and less commitment (Hudson, 2007).

Assessing the dominance of domestic political actors can be seen from proximity and how cohesive and fragmented domestic political actors are. "From the regime's perspective, the more proximate and the more cohesive an actor is, the more powerful the actor could become on the domestic game board (Hudson, 2007, p. 147)." From the perspective regime, the more dominant and cohesive an actor will have the greater power in dominating the domestic political conditions of a country. Besides that, in assessing the dominance of domestic political actors can also be seen from how much difference of view between the ruling regimes with the domestic political actors involved. The larger of different views on a particular issue, the greater the competition in determining the policy on the issue (Hudson, 2007).

In this regard, Hudson described how the regime's strategy is giving impact on foreign policy making as follows:

Douglas Van Belle's in his book titled Foreign Policy Analysis explains that the actions of a regime have two motivations, those are avoiding the desire to endanger someone's political career and the desire to improve someone's position in the political arena. Both motivations created several approaches conducted by the regime in facing the opposition parties which exist in policy-

\section{Figure 2. Linking Domestic Political Competition to Foreign Policy}

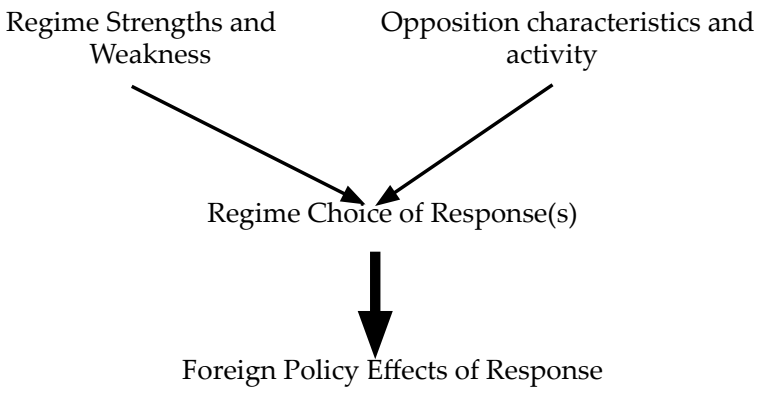

Source: V.M.Hudson, Foreign Policy Analysis: Classic and Contemporary Theory, Rowman E Littlefield, Maryland, 2007

making. Approach or strategy is divided into two, those are directly and indirectly. Direct tactics include neglecting and rejecting actions of the opposition party and which are against the policies of the government regime. Indirect tactics include diverting issues and compromising actions for opposition parties by opening "space" for opposition parties (Hudson, 2007). Based on these theories, this paper aims to answer the following question, "How do Progressive and Conservative groups in South Korea affect relations between South Korea, North Korea and the United States?"

\section{Literature Review}

International politics between South Korea, the United States and North Korea influence all three countries. The policy of one country has a reciprocal action and effect to the other two countries. As a result, the actions of other countries outside South Korea, US, and North Korea do not affect the international politics among these three countries, especially North Korea. Foreign policy of the United States to respond to North Korea gives the impact to solve the problem in the Korean Peninsula. However, the domestic political condition of South Korea has a significant effect in affecting relations between those three countries (Yoon, 2011). 
The significant role of South Korea for the US and North Korea could be assessed in some regimes in South Korea. The paper, "The Re-Evolution of The Sunshine Policy, Failure or Success?" explains about the different policy applied by Kim Dae Jung from the previous regime. This paper argues that Sunshine Policy is promoting the cooperation and views of society to create peace between both Koreas (Kwon, 2014). From that policy, we can see the relation of South Korea-North Korea that previously had a high tension turned into a cooperative relationship between both Koreas.

Another research explains the policy applied by President Roh Moo-Hyun, who was from a progressive group. The policies that were applied to face North Korea and the United States were similar to Kim Dae Jung's regime. Roh's government had two dimensions of foreign policy: doing the rapprochement to North Korea and controlling Bush's policy to make Kim Jong II's government weaker. In this case, South Korea changed their attitude towards the US and started to loosen up their close relationship. In 1980 and 1990, several social movements had come and reflected South Korea's independent characteristics to determine their own policy. They had a considerable influence on South Korea's condition and position in international, regional and domestic areas (Zhu, 2007).

However, it is different from Lee's government policy that focused on North Korea's nuclear power and made South Korea-United States relations stronger. It contrasts the previous regime. The paper, "Lee Myung-Bak Administration's North Korea Policy: Challenges and Tasks" shows the difference of policy in the Lee's government period with Kim Dae Jung and Roh Moo-Hyun's government period. We can see a significantly different policy because Lee sets the harder policy than before. The policy about reciprocal action should be symmetrical and not make South Korea become lost. Because, according to Lee's government, it has a relation that can affect each other (Park, 2008).

In this case, we can see that conservative and progressive groups have different views to face North Korea's nuclear weapons. The view of progressive groups is to reject the United States' domination in South Korea's politics. The view of the Sunshine Policy is to free South Korea from the United States' hegemony (Ho, 2012). In this case, progressive groups' movement can be called the Anti-American movement in South Korea. This movement had started to develop in 2000 when Kim Dae Jung led South Korea. Implementation of Sunshine policy represents thoughts and views of progressive groups in facing North Korea by cooperation. This is a challenge for conservative groups in South Korea. The challenge is both groups have different views in facing North Korea and the United States (Joong, 2010).

Based on these literatures, it could be seen that there are some differences in South Korea's foreign policy towards the US and North Korea during some periods. These differences are caused by the difference in ideology of South Korea's president in each period. Thus, the author sees a pattern formed by the relationship between South Korea, North Korea and the United States as South Korea's domestic political dominance has influenced reciprocal actions from North Korea and the United States.

\section{Methods}

This research uses literature study by looking closely at data taken from reports and journals that discuss South Korea's national politics. The theoretical framework by V.M Hudson is also applied as this framework focuses on domestic circumstances and national actors in a particular country. The author will start by looking at some policies made by conservative and progressive regimes in Kim Dae Jung, Roh Moo-Hyun, and Lee MyungBak's period. The assessed policy is domestic 
policy, which is related to policy in facing North Korea and the United States. The policy will produce a reciprocal effect from North Korea and the United States to South Korea's domestic political conditions. The ruling regime and domestic political conditions of South Korea determine the conditions between South Korea, North Korea and the United States. The indicators used to assess the policies of the ruling regime are the background of each regime in South Korea, the national reaction to the particular foreign policy and reciprocal action taken by the United States and North Korea as a reaction to South Korea's foreign policy.

\section{Results}

South Korea's domestic political conditions are affecting the relationships between South Korea, the United States and North Korea. When a president of a progressive group leads South Korea, South KoreaUnited States relations will stretch and South Korea-North Korea relations will increase. On the contrary, when South Korea is led by the president of a conservative group, South Korea-United States relations increases while South Korea-North Korea relations stretches. This is due to the differences between two groups in dealing with the United States and North Korea.

\section{Discussion}

\section{Conservative and Progressive Group Dominance in South Korea}

Leadership of progressive groups started from the election of President Kim Dae Jung in 1998. President Kim Dae Jung was a presidential candidate who came from a minority region in the seat of government in South Korea. This is reflecting the shifting views of the domestic society about the leadership of previous conservative groups. One of the factors Kim Dae Jung was elected as a president of South Korean is the condition of South Korea at that time. In 1997, South Korea was affected by the Asian financial crisis. The 1997 crisis affected the leadership of the previous conservative group. The impact is a critical view of society against the political and economic failures in the government of conservative groups (Chaebong, 2008). Leadership of progressive groups in South Korea continued in the government of Roh Moo-Hyun who was elected after Kim Dae Jung's government. President Roh Moo Hyun came from the Uri party, which is a fraction of the NCNP (New Millennium Democratic Party). Betrayal and differing views on facing North Korea can split this party (Chaebong, 2008). In this case, President Roh Moo-Hyun adheres to Sunshine Policy in facing North Korea (Lee, South Korea in 2002, 2003). In 2002, President Roh Moo-Hyun won with two-thirds of the votes earned from teenagers who began criticizing the United States' position in South Korea (Kang, 2008).

In Kim Dae Jung's government, the dominance of the progressive group was not too strong. It was demonstrated by the dominance of conservative groups in the National Assembly (Yu, 2016). Thus, the applied policies by Kim Dae Jung would always receive criticism and negative views from the opposition group. The policy can be seen from the implementation of the Sunshine Policy in facing North Korea. The criticism from opposition groups continued to thrive; these groups said that South Korea's policy is only a Give Away policy that does not benefit South Korea (Han, 2002). However, President Roh Moo-Hyun experienced different conditions while he governed. In 2004, Uri's party won 152 from 299 seats in the National Assembly (Chaebong, 2008). Therefore, the bargaining position of the progressive group would be stronger in applying the policy which links to the ideology of Progressive party. In the case of policy implementation in facing North Korea and the United States, domestic political actors in progressive regimes can be 
said to be cohesive. This can be demonstrated by the high positive percentage received in assessing the Sunshine Policy and Peace and Prosperity policy. The acceptance of the policy is shown by a poll conducted by the Ministry of Unification in Kim Dae Jung's government in 2000 which reached $80-90 \%$ (Levin, 2002). In 2002 at the end of Kim Dae Jung's leadership the percentage shown by Joongang Ilbo showed that $88.2 \%$ wanted the Sunshine Policy to be continued by the next South Korean government (Paik, 2002). Therefore, Roh MooHyun's government, which was supported by the 386th Generation movement and the anti-US movement, implemented policies to escalate cooperation with North Korea and try to reduce the US military forces in South Korea (Chaebong, 2008). The 386 group is a social movement in South Korea which was initiated by people in a group age 30s, went into college in 1980s and they were born in 1960. The 386 movement and anti-US had similar viewpoints in criticizing the US. Both groups had more sympathy for North Korea.

However, the failure of President Roh in controlling the rise of real estate prices and the failure to improve the education system became the internal factor of declining dominance of progressive groups in South Korea. In addition, the cooperation policy of President Roh in the Free Trade Agreement with the United States increased the negative domestic community's view that assess the policy had been inconsistent with the background and values held by the progressive group. It also caused a split among supporters of President Roh from a progressive group (Chaebong, 2008). This made South Korea turn on the conservative regime.

The dominance of the conservative group restarted with the election of President Lee Myung Bak as an actor who had the closest position to the foreign policy-making process. Furthermore, the dominance of the conservative group could be proved by its control in the National Assembly (Konishi M. , 2009). In 2008, the conservative group dominated with 167 seats or $57.4 \%$ from total seats in the National Assembly. Then, the dominance of this conservative group was also reinforced by a private media ownership policy by an institution. Conservative groups had a more dominant media than the opposition. Media dominated by conservative groups such as Chosun Ilbo, Donga Ilbo and Kookmin Ilbo (Levin, 2002). The dominance of this conservative group provided a strong bargaining position in determining domestic policy or foreign policy. In the implementation of foreign policy in facing North Korea, President Lee Myung Bak implements DOT 3000 policy. This was based on the conservative views who see that the action against North Korea should be with a balanced reciprocal action by what South Korea has got (Konishi M. , 2009).

The positive response of South Korean society then was changed with reciprocal actions by North Korea. The actions such as shooting of visitors in Mt. Geumgang area, banning South Korean citizens from entering Kaesong Industrial Complex and developing and conducting several nuclear weapons trials (Unification, 2012). In addition, North Korea's attack on the islands of Cheonan and Yeonpyeong was one of North Korea's over acts of provocation against South Korea (Unification, 2012). Therefore, in the President Lee Myung Bak's government, South KoreaNorth Korea relations were more conflictual. It can be shown by declining the positive view of Korea's unification from $63.8 \%$ in 2007 to $51.6 \%$ in 2008 . Later, the view increased again with a percentage of 55.8 in 2009. Meanwhile, the critical view of North Korea also increased from 31.1 percent, in 2008 by 49.5 percent, and in 2009 increased by 54.9 percent. The level of disbelief in the North Korea government has increased from 37.8 percent in 2007 and in 2008 to 50.3 percent (Park K. , 2010). This indicates 
that the higher threat by North Korea would make domestic political actors in South Korea more cohesive to look critically at North Korea.

On the other hand, this is affecting South Korea-United States relations under the conservative regime. In the early of Lee Myung Bak's regime, anti-US groups protested against the policy of beef imports from the United States. However, it turned around when North Korea restarted its nuclear experiment. Cooperation between South Korea and the United States was increasing, it can be seen by the percentage of global survey results that show the pro-South Korea's character against the United States reached $78 \%$. The views of the importance of relations between South Korea and the United States reached 87\% which is supported by North Korea's threats to South Korea (Konishi M. , 2009). This made the President Lee Myung Bak have a chance in increasing South Korea-United States military cooperation against North Korea. Some cooperation was the agreement of two countries in dividing the cost of placing the United States military force in South Korea. In 2009, the government permitted 28,500 US troops to enter South Korea (Konishi M. , 2009). Besides that, South Korea also joined the PSI (Proliferation Security Initiative) which was previously rejected by the progressive regime (Park K. , 2010).

The dominance of the conservative group is bigger than the progressive group. It is also cohesive to the government of President Lee Myung Bak. This is due to the position of dominant conservative groups in domestic political actors. Another point indicates that the positive views on North Korea has decreased from $23.8 \%$ to $20.3 \%$ annually. In contrast, the positive views of the United States increased from $53.0 \%$ in 2007 to $68.2 \%$ in 2009 . In the society aged 20 years, the positive view of the United States increased from $46.7 \%$ to $60.4 \%$ in 2007-2009 (Park K. , 2010).

\section{The Regime Strategy of Progressive and Conservative Group in Facing Opposition Group}

To assess the strategy of the ruling regimein South Korea, it is necessary to assess the strength and weakness of the regime. After assessing the strengths and weaknesses of a government regime then assess the characteristics of the opposition groups. This assessment will result in the strategy which links to its foreign policy. The South Korean government regime, which is led by progressive groups, has the power that is driven by the process of democratization that some community groups want to do, especially among adolescents. Democratization is when the policies carried out by the government are in accordance with the national consensus (Levin, 2002). The next strength of the progressive group in which criticism of the position of the United States in South Korea began to develop with the formation of the Anti-United States NGO group in South Korea (Levin, 2002). In this case, the social movement shared the views of President Kim Dae Jung and Roh Moo Hyun about the hegemony of the United States which was an obstacle in the unification process in South Korea (Chaebong, 2008). Pro-American were also seen as an economic system with continuous exploitation of workers done by Chaebol (Chaebong, 2008). In addition, the new thoughts and action which were offered by progressive groups in dealing with the threat of North Korea, is an added value to the strength of progressive government regimes (Chaebong, 2008). In other words, it becomes a new solution when compared to previous government regimes in creating peace between the two Koreas. New offers and actions here can be seen in the political and economic reforms that Kim Dae Jung wanted to do. The reforms here then represented the voices of minority groups that are marginalized by the previous domination of conservative groups (Chaebong, 2008). 
The strength of a progressive regime can be said to originate from several social movements that supported the promotion of democratization in South Korea. The progressive regime received support from the Anti-American movement and Generation 386 (Chaebong, 2008). This was indicated by the victory of President Roh over his impeachment case as president for violating the presidential political neutrality code. In this case, Roh decided to separate from the NMDP party and form the Uri party (Shin, 2012). Thus, the opposition GNP party questioned and wanted to impeach President Roh Moo Hyun. However, it ended with the victory of President Roh Moo Hyun, who was assisted by approximately two million South Koreans protesting the impeachment report (Shin, 2012). In that protest, there were 937 public organizations including PSPD, Environmental Movement United, CCEJ and Women's Movement Unions. This then shows that the strength of progressive groups came not from party support but from social movements in South Korea (Shin, 2012). In its relation to the US and North Korea, these social movements have a more pro-view of North Korea and Anti-America. Thus, the characteristics of this progressive regime are known as the policy of peaceful unification of Korea and anti-America (Chaebong, 2008).

On the other hand, the progressive regime showed a failure in increasing South Korea's economy. The failure then led to the weakening of support for the Kim Dae Jung and Roh Moo Hyun regimes (Park W. , 2016). In this case, supporters of President Kim and Roh then split into two groups in view of more priority policies. Some groups considered that egalitarian economic reform is a top priority in the policies that should be implemented. However, another group viewed that national unification had been a more prioritized policy (Doucette, 2010). In addition, Roh's policy initiative in collaboration with the United
States FTA is seen as a policy that is contrary to the values of progressive groups who seek to remove the influence of US imperialism in South Korea (Chaebong, 2008).

In contrast, the conservative group had different views from the progressive regime. The views of conservatives are more anti-North Korean and anti-communist. The conservatives are more pro-view of the United States and support the military cooperation of South Korea and the United States (Shin, 2012). These opposition groups are also often referred to as "American Collaborators", "Anti-Democratic Fascist", and "Monopolistic Capitalist" (Chaebong, 2008). In this regard, opposition groups criticized the progressive regime as a 10-year failure of South Korea which had caused a regression among the South Korean people. In this case, the economic assistance provided by President Roh to North Korea had caused difficult economic conditions in South Korea (Shin, 2012). The failure of President Roh in controlling the rise in real estate prices. In addition, the cooperative policy undertaken by President Roh in the Free Trade Agreement with the United States enhances negative public views in accordance with the backgrounds and values held by progressive groups (Chaebong, 2008).

In this case, progressive government regimes used tactical strategies of neglect and compromise. The neglect tactics are the same as policy implementation against North Korea. This was demonstrated by the implementation of the Sunshine Policy applied by Kim Dae Jung and continued by the Peace and Prosperity policy of Roh Moo-Hyun's government. Both policies have a common ground which is opening dialogue between the two Koreas through cooperation (Choi, 2010). These policies are criticized by opposition parties as a "give away" in which South Korea does not gain significant benefits from North Korea. Besides that, this policy is also often criticized as a one-sided policy that did not reach an 
agreement in the opposition-held National Assembly (Paik, 2002). Therefore, Kim Dae Jung's government enacted a centralized government conducted by appointing several important institutions to be filled with people who have high loyalty towards him. This made political stability become strong in implementing reform policies (Kim, 2000). In terms of relations with the United States, the progressive government regime made some compromises with the characteristics of opposition groups who viewed the alliance's relationship with the United States as important. This was demonstrated by the cooperation in the field of economy that was fixed in the government of Roh Moo Hyun in 2007 covered by the Free Trade Agreement. In addition, the government of Roh Moo Hyun also sent military troops to Iraq in accordance with the request of President Bush (Bae, 2010). In other words, the progressive regime here made some compromises in looking at relations with the United States. In this regard, the two Presidents Kim Dae Jung and Roh Moo Hyun agreed to reduce the increasing anti-United States tension in South Korea. The two presidents stated that the United States is South Korea's main alliance (Zhu, 2007). The progressive regime made some compromises while maintaining some cooperation with the United States in the midst of the development anti-American movement in South Korea.

Whereas in a conservative government regime had strength in its dominance in the National Assembly. In the Lee Myung Bak government, conservatives had a dominance of $57.4 \%$ of the total seats in the legislature (Konishi M. , 2009). In addition, the strength of the conservative regime also came from conservative social movements. Conservative groups formed the New Right Union in 2005. This social movement is a social movement that is different from before such as veterans' organizations, business groups, and the media (Shin, 2012). In this case, NCU holds a different basic argument than the previous "old right." This movement is more focused on the struggle for community rights and interests in fighting for democracy (Shin, 2012). In addition, this movement has an important role in influencing the views of conservative people and mobilizing the people for Lee Myung Bak's victory in 2007. The movement also criticized the previous regime as a communist regime and pro-North Korea (Shin, 2012). In addition, the strength of the conservative regime comes from business groups in Chaebol which are products of the conservative regime. Business groups such as Chaebol want government policies that are friendlier to business groups and reduce tax on each business group (Mun, 2009). In addition, the role of the media, which had been dominated more by conservatives became a power for conservative government regimes in moving public opinion through the media. Media dominated by conservative groups include Chosun Ilbo, Donga Ilbo, and Kookmin Ilbo (Levin, 2002). In this case, President Lee Myung Bak gave a policy of private ownership of the media. Aimed to control the media and mobilize the opinions of the South Korean people (Shin, 2012).

The conservative regime took a similar action to deal with the opposition, including the abandonment and the compromise. In the case of abandonment, the conservative group regime enhanced alliance relations with the United States in all fields. This was demonstrated by establishing cooperation in enhancing ROK-US alliance relationships in $21^{\text {st }}$-century alliance strategies (Lee, 2008). This cooperation includes military and economic cooperation between South Korea and the United States. Military cooperation was manifested in South Korea's approval for the cost sharing in the implementation of the US forces in South Korea (Konishi M. , 2009). In addition, South Korea also agreed to join the PSI (Proliferation Security Initiative) pioneered by the United States in handling North Korea's nuclear threat (Park 
K. , 2010). A compromise was being made in determining the attitude towards North Korea. This was indicated by the change in DNO 3000 Vision (Denuclearization and Opening 3000) policy to MBCP (Mutual Benefits and Common Prosperity) caused by the protests put forward by the domestic community on the reciprocal actions taken by North Korea. In addition, the government of Lee Myung Bak also opened a discussion room in the community about the dangers of the North Korean threat, especially among teenagers (Unification, 2012). The humanitarian aid which was stopped by President Lee was then resumed due to protests from the community and NGO groups in South Korea. President Lee continued the food aid without any conditions, and it was based on humanitarian assistance (Park, 2008).

\section{Conclusion}

South Korea is one of the alliance countries of the United States which borders directly with North Korea. South Korea - North Korea relations are influenced by the ruling regime in South Korea. It also has an impact on South Korea-United States relations. In this case, after the Korean War South Korea tended to depend on the United States. This is due to two things, the first is the unstable condition of South Korea and the second to maintain security from North Korea. However, this later underwent a change in the regime of Kim Dae Jung's government. In the government of Kim Dae Jung, South Korea had to be able to escape from the United States' influences. In addition to that, relations with North Korea must be established through a cooperative approach. This pattern was the opposite to the actions of the previous government. The pattern of relations was then continued in the reign of Roh Moo Hyun. Thus, these two government regimes can be said to be progressive governmental regimes. Progressive group policies are policies that are closer to North Korea and reduce the intensity of relations with the United States.
Meanwhile, a different action was taken in Lee Myung Bak's leadership as he was more influenced by the conservative group. In Lee Myung Bak regimes, the government tried to restore South Korea's relations with two countries as before. In this case, President Lee Myung Bak increased the intensity of cooperation with the United States. Because in the view of conservatives, the alliance relations between the two countries are the main priorities of South Korea. The position of the United States here is also seen as a country capable of maintaining security stability on the Korean Peninsula. In terms of relations with North Korea, President Lee Myung Bak chose a policy that directly referred to the development of its nuclear weapons. According to conservatives, the problem of achieving peace on the Korean Peninsula is caused by the development of nuclear weapons. Therefore, the action that must be taken is to force North Korea to stop the development of nuclear weapons. In other words, the government under the conservative group had different patterns compared to the previous regime. This is indicated by the increasing intensity of relations with the United States. Meanwhile, relations with North Korea can be said to be declining.

Based on the views of two ruling regime groups in the South Korean government, there are different views in facing the United States and North Korea. The progressive group viewed that South Korea should be able to escape from the domination of the United States and establish cooperation relations with North Korea to bring peace between both Koreas. Meanwhile, the government of conservative groups saw that South Korea's top priority is an alliance relationship with the United States and North Korea's threat must be dealt with strongly and firmly. The actions of the two regimes produced reciprocal effects from North Korea and the United States. It is affecting the pattern of South Korean relations 
with both countries. When South Korea is led by a president from a progressive group, the relation between South Korea-North Korea is more cooperative. It has a direct impact on the relation between South Korea and the US. However, when South Korea is led by a president from a conservative group, the relation between South Korea - North Korea is conflictual. It also affects the relation between South Korea and the US. Hence, South Korea's domestic political conditions are affecting the relation between South Korea with the United States and North Korea.

\section{References}

Bae, J. Y. (2010). South Korea Strategic Thinking Toward North Korea: The Evolution of The Engagement Policy and Its Impact Upon US-ROK Relation. Asian Survey 50(2), 335355. doi: 10.1525/as.2010.50.2.335

Chaebong, H. (2008). South Korea Miraculous Democracy. Journal of Democracy 19(3), 129-142. Retrieved January 10, from, https://www.rand.org/pubs/reprints/ RP1370.html.

Choi, J. K. (2010). Sunshine Over a Barren Soil : The Domestic Politics of Engagement Identity Formation in South Korea. Asian Prespective, 34(4), 115-138. doi: 10.1353/ apr.2010.0008.

Doucette, J. (2010). The Terminal Crisis of The "Parcipatory Government" and The Election of Lee Myung Bak. Journal of Contemporary Asia, 40(1), 22-43. DOI : doi: 10.1080/00472330903270338.

Han, Y. S. (2002). The Sunshine Policy and Security on the Korean Peninsula : A Critical Assesment and Prospect. Asian Prespective, 26(3), 37-69. Retrieved January 7, 2018, from http://www.jstor.org/ stable/42704373.

Ho, M.S., \& Hong, C. S. (2012). Challenging New Conservatice Regimes in South Korea and Taiwan. University of California Press, 52(4), 644-665. doi: 10.1525/as.2012.52.4.643.
Joong, H. J. (2010). The Rise and Fall of Anti American Sentiment in South Korea. University of California 50(5), 946-964. doi: 10.1525/as.2010.50.5.946.

Kang, W. T. (2008). How Ideology Divide Generation: The 2002-2004 South Korean Election. Canadian Jurnal of Political Science 41(2), 461-480. doi: 10.1017/ S0008423908080438.

Kim, S. (2000). The Politics of Reform in South Korea : The First Year of the Kim Dae Jung Government 1998-1999. Asian Prespective, 24(1), 163-185. Retrieved January 9, from https://www.jstor.org/ stable/42704252?seq=1.

Lee, H. Y. (2003). South Korea in 2002 : Multiple political dramas. Asian Survey, 43(1), 6477. doi: 10.1525/as.2003.43.1.64.

Lee, S. H. (2008). ROK-US Relation in Lee Myung Bak Government: Toward a Vision of a '21st Century Strategic Allience. The Journal East Asian Affairs, 22(1), 1-32. Retrieved February 15, 2018, from http:// www.jstor.org/stable/23257872.

Mun, C. I. (2009). South Korea in 2008 : from crisis to crisis. Asian Survey. 49(1), 120-128. doi: 10.1525/as.2009.49.1.120.

Paik, H. (2002). Assessment of the Sunshine Policy: A Korean Prespective. Asian Prespective 26(3), 15-35. Retrieved February 15, 2018, from http://www.jstor.org/ stable/42704372

Park, J. C. (2008). Lee Myung-Bak Administration's North Korea Policy : Challanges and Tasks. The Journal of East Asian Affairs, 22(2), 39-61. Retrieved February 15, 2018, from www.jstor.org/ stable/23257896.

Park, M., \& Lie, J. (2006). Economic Dynamism, Generational Conflict, and Social Transformation. Asian Survey 46(1), 5662. doi: 10.1525/as.2006.46.1.56.

Park, M. K., \& Kim, P. (2010). Inter-Korean Relation In Nuclear Politics. Asian Prespective 34(1), 111-135. doi: 10.1353/apr.2010.0034. 
Park, S. H., \& Wilding, M. (2016). The Politics Government Reform in Korea : From Tripartite to Bipartite Politicization. Administration and Society 48(9), 1059-1084. doi: 10.1177/0095399714527753.

Shin, K. Y. (2012). The Dillemas of Korea's New Democracy in an Age of Neoliberal Globalisation. Third World Quarterly 33(2), 293-209. doi: 10.1080/01436597.2012.666013.
Yoon, J.H. (2011). The Effect of US Foreign Policy on Relationship Between South and North Korea. Journal of East Asia Studies 11(2), 255-287. doi: 10.1017/S1598240800007189 Zhu, Z. (2007). Small Power, Big Ambition : South Korea's Role in Northeast Asia Security Under President Roh Moo-Hyun. Taylor and Francis, Asian Affairs 34(2), 6786. doi: 10.1017/S1598240800007189. 